\title{
Regional currency areas and international financial architecture in financial globalization: an introduction
}

\section{Patrick Artus, André Cartapanis and Florence Legros}

\section{THE CHALLENGES ARISING FROM FINANCIAL GLOBALIZATION}

Theoretically, the globalization of financial markets is likely to generate an efficient allocation of resources on a worldwide scale. In addition to the advantages already provided by international specialization, one has to add the possibility of transferring financing capacity to economies suffering from a shortfall in savings, and also of smoothing over time the lack of adjustment between savings and investment triggered in each country by the overriding need to develop infrastructure, specific demographic features, the life cycle of households or the state of public finances. In an increasingly uncertain world, financial innovation also gives rise to possibilities of hedging and transferring risks that did not exist in the past.

But simultaneously international capital movements can lead to greater fragility and chronic instability in international financial markets. In a context of asymmetry of information and short-sightedness in decisionmaking, the decisions with respect to portfolio reallocation by international investors in the asset markets and the brutal discontinuation of loans extended by international banks can respond to herd-like rationality, endogenous changes in expectations reflecting swings in perceived insecurity, without any significant deterioration in macroeconomic fundamentals. Such episodes are likely to disrupt the determination of asset prices and the allocation of savings on an international scale, triggering crises and leading to huge social costs. Thus the 1990 s saw a rash of currency crises, with wild fluctuations in exchange rates, along with massive losses of currency reserves and reflected by a steep devaluation or the floating of a currency which had been pegged until then, or by a severe and sudden depreciation when they were in a situation of dirty float. The currency crises of the 1980s and 1990s 
are estimated to have created cumulative deficits in output, relative to the long-run trend, ranging from 4 per cent to 7 per cent, and twin crises, combining banking and currency crises, resulting in losses in production of around 15 per cent. The magnitude of these shocks is explained by the size of the capital inflows and outflows. During the Asia crisis of 1997, net capital outflows from the five worst-hit countries, that is Thailand, Malaysia, Indonesia, the Philippines and South Korea, thus exceeded US $\$ 100$ billion, or about 10 per cent of their aggregate GDP, in a few months.

Against this backdrop, the official doctrine justifying the liberalization on a vast scale of capital markets, once presented as a prerequisite for the economic development of emerging countries, according to the yardstick of the Washington consensus, now seems far more tentative. There is no irrefutable empirical evidence of a positive link between the international financial integration of developing economies and their growth rate. Conversely, volatility of macroeconomic performances and vulnerability to crises have increased significantly. Faced with the experience of massive capital inflows and outflows creating pro-cyclical and disruptive effects, one can consider that there is no longer any neo-liberal Washington consensus. The triumph of the market and financial globalization certainly does not mean that states must withdraw from the international financial arena. All the initiatives adopted by the international community for the last ten years, including central banks, the BIS and the IMF, refer to the principle of international capital mobility, while acknowledging furthermore the need for an institutional infrastructure capable of correcting the inherent flaws of international financial markets. But how can this be achieved?

\section{WITH THE NEW INTERNATIONAL FINANCIAL ARCHITECTURE, A NEW BRETTON WOODS IS NOT ON THE AGENDA}

Everybody admits that it is politically unrealistic to want to build a new international monetary and financial system by drawing on supposedly cast-iron rules, which international institutions benefiting from widespread transfers of competences would be in charge of enforcing. This is why the reforms known as the new international financial architecture, sketched out in June 1999 under the aegis of the G7 and implemented since then by the IMF, are not aimed at leading to a new Bretton Woods - that is the reconstruction of a monetary and financial system on a global scale - but less ambitiously seek to improve the functioning of financial markets, especially in emerging countries. This purpose in principle encompasses four objectives: improve transparency and access to information; modernize the prudential regulation of 
financial institutions; reinforce the role of existing financial international institutions and reform their modes of intervention to meet the challenges of market instability more adequately; correct the system of incentives that shapes decision-making in the private sector and ensure the private sector shoulders an appropriate share of the burden during a crisis.

The question of exchange rate regimes - and one needs to keep in mind that this was at the core of the Bretton Woods system - therefore is not explicitly mentioned in the agenda of the new architecture. Nevertheless the repetition of international financial crises throughout the 1990s and 2000s cannot be dissociated from the options adopted in terms of exchange rate regimes: stepping up the target zone system, in Europe in the run-up to EMU and the creation of the euro; pegging to the dollar in many emerging economies such as Mexico or Thailand; the setting up of a currency board in the case of Argentina. As is well known, these choices led to a string of severe crises, in 1992-93, in 1995, in 1997 and in 2002. Hence the renewed relevance of the Mundell triangle of incompatibility.

\section{THE CHOICE OF AN EXCHANGE RATE REGIME: CORNER SOLUTIONS OR INTERMEDIATE REGIMES?}

Economists have recently rediscovered a principle set out by Mundell as early as the 1960s: only corner solutions, that is pure flexible exchange rates or hard pegs, such as dollarization or a currency board, would be durably sustainable in a context of high capital mobility and, conversely, intrinsic fragility allegedly characterizes intermediate exchange rate regimes.

But this stance does not enjoy unanimous backing. It is often argued that intermediate regimes not only can remain, but also offer real advantages for emerging economies by combining the virtues of exchange rate stability, notably from the viewpoint of monetary discipline, without creating dangerous irreversible situations as illustrated by the meltdown of Argentina's currency board. It can even be argued that no exchange rate regime is optimal in absolute terms, as the optimal choice could prove to be different not only according to country but also according to the period for any one country. A currency float can be the best solution for more developed countries or for the most highly integrated economic zones, and therefore between the dollar, euro and yen zones. Exchange rate fixity can prove to be preferable for small economies, which are very open to the exterior or where hyperinflation prevails. Intermediate regimes can respond to the diversity of mixed situations. All the more so, as adopting a fixed exchange rate regime, typically when joining a currency area, can generate significant modifica- 
tions in ex ante choice parameters, be it the degree of external openness, the weight of intra-zone trade or the correlation of cycles within a currency area.

However debates about the choice of an exchange rate regime and the consequences it can entail have changed in nature to some extent, if they are compared with the post-Second World War debates about the respective pros and cons of fixed and flexible exchange rates. One no longer seeks to assess the advantages and the drawbacks of each exchange rate regime on the scale of the international monetary system, with either option to be applied to all economies, by preferring the question of external adjustment, and absorption of imbalances in current account balances. On the contrary one now looks with respect to each national economy, or even at a regional level, at the type of exchange rate regime that seems to be the best choice, from the viewpoint of the efficiency of overall macroeconomic steering as well as in reference to the sustainability of the regime in a context of financial globalization. The range of possible options has widened substantially. Regarding flexible exchange rates, one draws a distinction between pure floats and dirty floats. With regard to fixed exchange rates, extreme solutions can be adopted: a currency board, dollarization (or euro-ization), creation of a currency area and so on. But one can also envision the implementation of a whole range of intermediate regimes: target zone-like fluctuation bands, pegged to a central nominal or real parity; crawling pegs; pegs that are more or less adjustable to a key currency or a basket of currencies; and so on. As a result, fresh analyses have enabled the criteria to be used to choose an exchange rate regime to be fine-tuned.

\section{NEW CRITERIA TO MAKE CHOICES AMONG THE VARIOUS EXCHANGE RATE REGIMES}

The specialized literature dedicated to exchange rate regimes and regional currency areas rapidly became a cottage industry in the late 1990s. But even if we were to restrict our study to corner solutions, we could not talk about the supposed theoretical superiority of either regime, and the situation we face resembles more a trade-off between the costs and the advantages of both. At the same time the criteria drawn upon to choose an exchange rate regime must now factor in the new deal that consists of financial globalization. We will now look at both sides of the argument in more detail.

Fixed exchange rates present the advantage of reducing uncertainty and therefore the currency risks weighing on international trade or international transfers of savings, lowering risk premiums and the cost of access to international capital markets, ensuring a credible anchoring for monetary 
policy, reducing spreads on an international scale, opposing the monetary financing of budgetary imbalances, preventing competitive depreciation policies, and so on. Simultaneously some drawbacks are inevitable: the credibility of the commitment in favour of fixed exchange rates is fragile and the triggering of a currency crisis can prove to be very expensive; monetary policy gets to depend significantly on the options taken by the country it has pegged its currency to; the economy becomes very sensitive to external shocks, but also to real shocks of domestic origin; there can be an overvaluation of the exchange rate likely to generate a deterioration in external trade and an unsustainable rise in unemployment; and so on.

The following characteristics are found on the plus side for flexible exchange rates: the independence of monetary policy, the neutralization of external shocks or real shocks thanks to changes in exchange rates, but also the absorption of effects on external competitiveness from an acceleration in inflation. Among the drawbacks note the risk of imported inflation, the contraction in international trade or transfers of savings when there is significant currency volatility, the risk of competitive depreciation policies developing within a given regional area, even the lack of incentive to implement adjustment policies or structural reforms.

In the past few years however, new theoretical arguments have completed the debate. Some authors operate within a political economy of exchange rate regimes and examine the political cost of macroeconomic adjustments according to the exchange regime that has been chosen. Others favour what they call the 'fear of floating,' in other words the counterproductive effects of floating when there is large external indebtedness denominated in currencies. As for the proponents of intermediate regimes, they draw on a whole range of criteria stemming notably from the theory of optimal currency areas to justify possibly choosing such a regime: degree of openness and magnitude of domestic or external shocks, whether symmetrical or asymmetrical; internal mobility of factors; degree of transmission of exchange rates to domestic prices; significance of credibility effects; aversion to inflation; and so on.

Apparently however this debate made progress via the discussion of the empirical experience of exchange rate regimes, notably in the 1990s. The question of the choice of an exchange rate regime inevitably suffered from interferences as a result of the high number of currency crises, among European countries firstly, in the early 1990s, and subsequently in emerging countries. The debate about the determinants of exchange rate regimes therefore cannot be dissociated from financial liberalization and the wild swings in capital movements in Asian or Latin American emerging countries. It has to be widened to the question of the vulnerability of fixed or target zone exchange rates. For the choice of an exchange rate regime, de 
jure or de facto, undoubtedly depends on normative criteria such as an optimal currency area (mobility of factors, degree of openness, indexation of wages and so on) or the preference function of policy-makers. But it also relates to financial factors that have to do with the sustainability of the regime or the lack of sustainability of the exchange rate regime that prevailed earlier, until a crisis imposed a change. For emerging countries, this macro-financial dimension (external indebtedness, exposure to the spreading of speculative outbreaks, relative weight of direct investment and banking or portfolio flows, volatility of capital movements, recent experiences of currency crises and so on) can prove to be decisive in terms of the credibility of a fluctuation band, such as a target zone.

But globalization, from the point of view of international trade as well as with regard to savings flows, has gone hand in hand with an intensification of regional relations, and this leads to the question of exchange rate regimes being widened to the analysis of regional currency areas.

\section{BEYOND EXCHANGE RATE REGIMES, THE RENEWED RELEVANCE OF REGIONAL CURRENCY AREAS}

Once more, it is primarily on the basis of the experience of the 1990s that the relevance of regional currency areas within emerging countries has been reasserted.

The example of the European Monetary Union and the creation of the euro have given rise to new projects. This is the case of the strategy envisioned for ASEAN countries within the framework of the Chiang Mai initiative: these economies could indeed choose an intermediate exchange rate regime, such as a target zone, in the prospect of eventually joining a future Asian regional currency area. This is also a hypothesis looked at by some Mercosur countries, Brazil and Argentina notably, which are thinking about a similar model.

But these initiatives result above all from the lessons drawn from the systemic crises that hit these countries in the second half of the 1990s. One merely needs to keep in mind the role played by the way the Thai crisis spread throughout the region to all of South-East Asia in 1997 or how stock market volatility spread within the South American continent in the autumn of 1998, and even more strikingly, think about the effects induced by the floating and the depreciation in the Brazilian real on the sustainability of Argentina's currency board. At a theoretical level, in the most recent models, systemic currency crises punish a widespread lack of coordination, as the taking into account of the excessive risks accumulated in some countries 
could result in mounting fragility in the neighbouring countries, regardless of their own situation at a macroeconomic level or with respect to their external financial commitments. If a local shock occurs, expectations can spread mistrust with respect to other currencies, in the direction of other economies, under the form of transfers of volatility or changes in asset prices, according to various channels of contagion: readjustment of all international portfolios (assets or banking debts) when uncertainty becomes widespread and consequently triggers pure contagion: spillover effects linked to trade or financial interdependences at a regional scale, or in response to a common creditor, and so on.

If the risk of a currency crisis depends not only on the weaknesses of a national economy but also, and even first and foremost, on the perception held by international investors about the situation of neighbouring countries, then the debate about the choice of an exchange rate regime turns into a discussion about regional currency unions, about their pros and cons, and about the criteria that each candidate must comply with to join this area.

The theory of optimal currency areas proposes an uncompromising vision of a fixed exchange rate system, since the purpose consists not only in designing a system of irrevocably fixed exchange rates but also in transferring to the currency areas sovereign responsibility for monetary policy and the exchange rate policy with the rest of the world. Hence the high number of question marks about the convergence criteria required ex ante, but also about the degree of freedom and the ex post mode of economic policy coordination insofar as the currency area entails some kind of budgetary federalism that preserves national prerogatives in this field. From such a point of view, it is not certain that the theories of optimal currency areas $a$ la Mundell or $\grave{a}$ la Kenen are currently the most robust in terms of answering these questions. On the one hand, the European Monetary Union was made up by a group of countries that did not meet the theoretical criteria of an optimal money area - whether with respect to the mobility of factors or to real wage flexibility. On the other hand each emerging country of a given regional zone, in Asia, Latin America or the Caribbean, presents specific attributes with regard to the degree of liberalization of financial markets or the relative weight of various modes of external financing (direct investment, sovereign debt, portfolio investment on the stock markets) and is therefore exposed to specific financial vulnerabilities. These are all phenomena that the theoreticians of optimal currency areas have deliberately neglected, but that one should however take into account to ascertain the financial sustainability of a regional currency area.

Thus the implementation of real regional currency areas in response to globalization and financial instability in emerging or transition countries seems premature. This then brings us back to the optimality and the 
vulnerability of intermediate exchange rate regimes within a regional zone, and raises many questions about common pegging, the forms of cooperation and/or coordination required at a macroeconomic or macrofinancial level, the leeway for exchange rate flexibility within a regional target zone, and so forth.

\section{THE SANTIAGO COLLOQUIUM AND THE QUESTION OF REGIONAL CURRENCY AREAS IN THE CONTEXT OF FINANCIAL GLOBALIZATION}

Such is the historical and analytical environment in which the international colloquium Towards Regional Currency Areas was held in Santiago, Chile on 26 and 27 March 2002. During the colloquium, a great number of themes relative to regional currency areas were dealt with: exchange rate regimes and optimal currency areas theory, exchange rate regimes in emerging countries, international capital markets and regional currency areas, the experience of the creation of the EMU and the euro, exchange rate regimes in Central and Eastern Europe, Asia and Latin America, dollarization, the coordination of macroeconomic policies in the presence of regional currency areas, and so on.

This book offers a selection of interventions dealing with the key issues and challenges of regional currency area projects in the context of financial globalization.

The interventions focus on the three central questions and the answers offered are presented in the three parts that make up the book:

- What effects can be expected from the creation of regional currency areas on the efficiency and the stability of international financial markets?

- In view of recent experiences, how have emerging countries chosen their exchange rate regimes or the currency they have pegged their exchange rate to (dollar, euro and so on)? What result can be already drawn, notably from the point of view of effects on the regional integration of each zone?

- What are the implications of choices of exchange rate regimes in terms of economic policy, within a monetary union, as in Europe, as well as with regard to international coordination? 


\section{INTERNATIONAL FINANCIAL MARKETS AND REGIONAL CURRENCY AREAS}

The first chapter in this book tackles the issue of the determinants and effects of the creation of regional currency areas: 'Financial market aspects of regional currency areas' is by John Hawkins and Marc Klau. After reviewing the favourable conditions and factors in terms of the creation of a currency area, they highlight the following point. While the euro zone and the issue of dollarization in several countries rekindled the debate, the question of the impact on financial markets is not new but lacks a clear answer, because there is not a long enough track record. The authors thus propose an analysis of the impact of the creation of a currency area on the financial markets of the countries they study. Their conclusion is quite mixed: probably, the creation of a currency area is a factor of stability and efficiency for financial markets. Nevertheless it is in no case a sufficient condition and is absolutely not a remedy for the 'original sin' of some countries, unable to raise capital in the international markets.

If, as the following chapter, 'Currency regimes and the process of regional financial integration of the emerging countries', tells us, belonging to a currency area implied a degree of homogeneity between countries, there would simply be an arbitrage between assets of major currency areas and, little by little, integration of emerging countries. This is precisely this 'distance from integration' that Daniel Goyeau, Jacques Léonard and Dominique Pépin measure, showing the weight of what they call 'geographical proximity' in contrast with 'monetary proximity'. The authors show that integration is generally more geographical then monetary, and this conclusion is confirmed by many other chapters in this book.

The impact of what they call 'social remoteness' is measured in the analysis of Alain Jousten and Florence Legros, 'Pensions and savings in a monetary union: an analysis of capital flows'. The question consists in understanding what are the implications of a currency area for the flow of savings between two countries hit by the same demographic shock but with very different retirement systems. Their chapter helps us to understand how the savings rate, and therefore capital movements between countries of the same economic union, could be changed by the demographic shock, and therefore how the weight of the demographic shock is shared between countries. Apparently countries with a regime of voluntary pension funds may have to bear a heavier demographic burden when they belong to a currency area than if they are not members of such a union; this burden entails a notably larger financial risk that could weigh on the holders of pension funds.

The chapter by Pierre Laurent and Jérôme Teïletche, 'Emerging sovereign bond markets: a view from the extremes' confirms the preponderance of 
geographical proximity in the financial integration between emerging countries. The authors draw upon a deliberately statistical approach to measure the risk inherent to emerging bonds from two angles: the usual, univariate approach and a more original one, a so-called multivariate approach, which takes into account contagion at an international level of shocks that affect emerging markets. While several well-known characteristics (heterogeneity of the term 'emerging countries', the nonetheless riskier feature of such assets, the decline in the risk of contagion since 1999) are reviewed, the method used by the authors, Extreme Value Theory - in other words, the failure of a normal distribution law to describe such financial assets - allows the authors to reveal a greater likelihood of a crash than a boom, and above all highlight the weight of geographical proximity in the combined risk of a crash. Geographical proximity would therefore be a factor of symmetry of shocks, and accordingly an element to be taken into account in order to determine the opportunity of creating a currency area. As much as the results it provides, the method used itself deserves further research: it is clearly extremely promising with respect to risk analysis, notably multivariate risk.

\section{EXCHANGE RATE REGIMES AND REGIONAL CURRENCY AREAS IN EMERGING COUNTRIES}

The purpose of the chapter written by André Cartapanis and Vincent Dropsy, 'Financial vulnerability and exchange rate regimes in Latin American and Asian emerging countries: towards new criteria?', is twofold: on the one hand it seeks to build indicators of exchange rate regimes that factor in not only the official regime - de jure exchange rate regime but also the actual regime-de facto regime - while on the other hand it tries to explain why these de facto regimes diverge from de jure regimes. For whereas de jure exchange rate regimes are designed to integrate the countries considered within currency areas, the de facto regimes are often designed to achieve a transition into these zones. The authors thus propose an analysis of the dynamics of exchange rate regimes that takes into account this convergence process. They show that the usual definition of optimal currency areas is not sufficiently precise to explain why an exchange rate regime is chosen, and one needs to take into account several additional variables to understand satisfactorily the choice of an exchange rate regime; notably, whereas financial depth argues in favour of exchange rate flexibility, international capital mobility would call for fixed exchange rates and foreign direct investment would not be a significant variable. The authors show that moreover there is effectively convergence between exchange rate regimes towards their level of long-term equilibrium. 
The following chapter by Luis Miotti, Dominique Plihon and Carlos Quenan, 'The dollar, the euro and exchange rate regimes in Latin America', also deals with the determination of the gap between de facto and de jure regimes, and attention is paid specifically to Latin America. The study concludes like the previous one on the importance of financial factors when rewriting the history of currency areas. For instance the history of the euro is illuminating with respect to this point as well as the importance of the period of transition towards an equilibrium exchange rate. Can this lesson bear fruit for Latin American countries? The statistical studies carried out show a significant proximity to the dollar zone, not only for Mexico as is often argued, but for all South American countries. A peg to the dollar is therefore natural. But pegging one's currency just to the dollar is a debatable, although simple, decision: policy is made more transparent, the market can test more easily the credibility of policies, and so on; but the relatively diversified structure (compared with Mexico's) of trade in most countries in Latin America could justify adopting a basket of currencies including the euro.

De facto peg or intermediate exchange rate regime with regional cooperation? This is the question posed by Agnès Bénassy-Quéré and Benoît Cœuré in 'Big and small currencies: the regional connection'. The following point has often been made theoretically: corner solutions are often preferable to intermediate solutions; empirically, de facto regimes sometimes diverge markedly from de jure regimes - stabilization of the regime because of the fear of floating, for example. The authors argue that debates about the optimal regime neglect the regional dimension and highlight the weight of geographic factors, emphasizing the difference between the sharing of a currency by a region (currency union with a supranational central bank) and the adoption of a peg currency (with a national central bank external to the region considered, for example in the event of dollarization). This geographical weight is therefore found for small currencies. Nonetheless the economies concerned can have an interest in regional cooperation around a peg to a basket of currencies rather than a corner solution.

'Regional integration and the issue of choosing an appropriate exchange rate regime in Latin America', by Hubert Escaith, Christian Ghymers and Rogerio Studart, also emphasizes the problems met in defining a peg for Latin American countries. They explore the two solutions proposed in the previous chapter: should one prefer a peg or a currency area? In other words, a foreign central bank or a regional central bank? Their answer is that - although Latin America is far from representing an optimal currency area - the latter solution could be preferable. On the one hand, it would give a common institution to the region and therefore probably a reason to cooperate with respect to shared macroeconomic targets. This is the 
argument of political economy based on the idea that centralized decisionmaking improves decisions. On the other hand, globalization develops a risk of strain on the financial markets and therefore enhances the attractiveness of the regional zone. Naturally these arguments point to the desirability of reinforcing the regional dimension that becomes no longer just a geographical but also an economic argument, with the purpose of providing an incentive for macroeconomic stabilization.

A regional rationale also provides the basis for the questions about the opportunity of a currency area in CARICOM (the Caribbean Community and Common Market, created in 1973) in 'Is a monetary union in CARICOM desirable?', by Olivier Manioc and Jean-Gabriel Montauban. The answer to this question raises two other problems. The first is: has regional trade integration been effective - in other words, is the region likely to become an optimal currency area? The second is: will trade be facilitated by the creation of such a currency area? Can cooperation be achieved between these countries? The authors answer the first question negatively: the goods produced are more substitutable than complementary and the potential of trade, in all likelihood, has already been achieved. They answer the second question by arguing that apparently differences in cycles between countries, and accordingly differences in terms of optimal cyclical reactions, also lead to a negative answer.

\section{REGIONAL CURRENCY AREAS AND ECONOMIC POLICY}

The first chapter in Part III, 'Exchange rate regimes in the route to EMU', by Michel Aglietta, Camille Baulant and Sandra Moatti, seeks to describe the transition of Eastern European countries and the slow move by these economies towards the euro. It also highlights, as the previous contribution did, real factors. The point highlighted by the authors is the diversity of paths followed by Central and Eastern European countries to move in this direction. These diverging approaches are correlated to the specific domestic conditions of countries: state of financial markets naturally, but also the level of inflation required for technological catching-up by countries and, notably, corporate borrowing requirements, the level of public expenditures needed for catching up in the fields of health, welfare, and so on. They thus establish a real need for soft and differentiated convergences to avoid endangering growth in the countries they study.

If foreign direct investment has no more than an indeterminate relationship with the choice of an exchange rate regime, as was already demonstrated in the chapter by André Cartapanis and Vincent Dropsy, the 
volume of foreign direct investment and, accordingly, that of induced employment hinges to a great extent on the tax system adopted by the various countries of a same currency area. In this chapter, 'Can the freerider behaviour of small countries offset the profligacy spending bias of large countries in the euro zone?', Patrick Artus examines the case of two countries in the same zone, different in terms of their size and their priorities on government expenditure, as the large country has a greater preference for government expenditure, just as is the case in the euro zone. The question then consists in ascertaining whether it is necessary to choose tax cooperation in the money area or if, on the contrary, tax competition is necessary to force the large country to change over to a more reasonable and less detrimental behaviour. In his model, Patrick Artus shows that the greater the difference in size between countries, the more any move of capital from the large country to the small one will have a major impact for the small country and a negligible one for its large partner. As a result, coordination of tax policies leads to higher taxes in the small country and thus a decline in its well-being. Asymmetrical coordination - in which large countries weight more than small ones - would therefore provide an incentive for spending while reducing well-being in small countries. Conversely a policy of tax competition increases well-being in the small country without however correcting the large country's profligacy. The most common practice in the euro zone, that is asymmetrical coordination, is therefore probably the worst of the three options.

Pierre Faure's chapter, 'Comparing monetary and fiscal policies in Europe and in the United States: a strategic analysis', seeks to assess the degree of coordination of European policies. One idea is that the decentralization of budgetary and tax decisions means the European Central Bank enjoys even greater freedom of action and, by contrast, the fact there is a single central bank facing a high number of budgetary decision-makers loosens the links between the central banker and regional policy-makers. Compared with the situation in the United States, Europe's situation tends to change substantially strategic interdependences between decisionmakers and therefore the results of the economic policies implemented. Insofar as cooperation exists between a subset of players, this hardens the position of the others. Accordingly, budgetary federalism is efficient only if there is cooperation between tax and budgetary authorities. Moreover the structure of European government means that appointing a hawkish governor of the European Central Bank is detrimental for the entire world, as it gives rise to a lack of coordination within the euro zone and also at an external level.

While the credibility of monetary policies has fuelled an abundant literature, the same point does not hold for the credibility of fiscal policies. The 
chapter written by Jean-Pierre Allégret and Marie-Noëlle Cales, 'Fiscal policy and war of attrition: the case of Latin American countries', deals with this point, and more precisely with reference to the case of Latin America. The authors show that if South American authorities have been led to implement extremely restrictive fiscal policies since the 1990s, this was because their previous behaviour had often been lax and they had to win back credibility, even though the cost of these adjustments in terms of growth was high. Seeking to achieve credibility thus implies - as is the case for monetary policy - a conservative fiscal policy that ends to avoid the inflationary bias, but which is reflected by some indifference to the real implications of the policy pursued.

Obviously these two characteristics often lead economists to criticize the monetary policy conducted in the euro zone. Jean-Jacques Durand, Nathalie Payelle and Virginie Traclet, in the last chapter of the book, 'Are there benefits to a monetary policy rule in the EMU?', look back at the recent past by asking what effects the disappearance of pre-EMU rules had - and, notably, of the McCullum Rule since it prevailed under a modified form before the appearance of the European Central Bank. From the experience of three major countries, France, Germany and Italy, it would seem that maintaining such a rule would have led to at least comparable results to those that have been obtained. This justifies maintaining such a rule in the EMU, because of the expected gains in terms of transparency and credibility.

All in all, proximity between economies is an important factor for the implementation and the success of a regional currency area. But this proximity must be geographical, and therefore trade-related, as well as financial. More generally speaking, proximity means one has to consider the models of economic development followed by member countries: weight of the state, homogeneity of tax provisions, type of external financing and insertion within financial globalization. The chapters gathered in this book thus make it possible to study in greater depth the conditions required for the creation of regional currency areas among emerging countries, but also their impact on a possible convergence of institutions or growth regimes. 